DOI: 10.12731/2658-6649-2019-11-5-64-68

УДК 557.15

\title{
ОЦЕНКА ПОКАЗАТЕЛЕЙ \\ АНТИОКСИДАНТНОЙ И ГЛУТАТИОНОВЫХ СИСТЕМ В КРОВИ ЗДОРОВЫХ ЛЮДЕЙ
}

Круглякова М.В., Смирнова О.В., Титова Н.М.

Кислород необходим для жизнедеятельности большинства живых организмов. Большая часть потребляемого организмом человека кислорода используется в прочессах генерирования энергии, но около 2-5\% переходит в активные формы кислорода (АФК), которые могут проявлять выраженное токсическое действие на клетки, инициируя окислительную модификация липидов и белков. Защита клеток, органов и всего организма от АФК, в целом, осуществляется антиоксидантной системой (АОC), важнейшими компонентами которой служит глутатион и ферменты его метаболизма.

Ключевые слова: супероксиддисмутаза (SOD); малоновый диальдегид (MDA); каталаза (CT); восстановленный глутатион (GSH); глутатион-S-трансфераза (GST); глутатионпероксидаза (GPO).

\section{PERFORMANCE EVALUATION OF GLUTATION AND ANTIOXIDANT SYSTEMS IN THE BLOOD OF HEALTHY PEOPLE}

\section{Kruglyakova M.V., Smirnova O.V., Titova N.M.}

Oxygen is necessary element for the life of most living organisms. Most part of the oxygen consumed by the human body is used in energy generation processes, but about 2-5\% metamorphose to reactive oxygen species (ROS), which can exhibit a pronounced toxic effect on cells, initiating oxidative modification of lipids and proteins. Protection of cells, organs and the whole body from ROS, in General, is carried out by the antioxidant system (AOS), the most important components of which is glutathione and enzymes of its metabolism.

Keywords: superoxide dismutase (SOD); Malon dialdehyde (MDA); catalase (CT); reduced glutathione (GSH); glutathione s-transferase (GST); glutathione peroxidase (GPO). 


\section{Введение}

Неотъемлемой частью жизнедеятельности большинства живых организмов является кислород. Он выполняет несколько функций: является конечным акцептором электронов в дыхательной цепи; необходим для образования АТР в процессе окислительного фосфорилирования; служит субстратом ферментов - оксигеназ и оксидаз [1]. Выявление молекулярных основ различных заболеваний и патологических состояний организма человека является одной из актуальных на сегодняшний день проблем современной медицины и биологии. Известно, что при многих заболеваниях нарушается прооксидантно-антиоксидантное равновесие, в результате чего интенсифицируются свободнорадикальные реакции и развивается окислительный стресс. Было доказано, что окислительный стресс с избытком активных форм кислорода участвует в различных физиологических процессах, таких как пролиферация, апоптоз и некроз [2]. Считается, что у человека окислительный стресс участвует в развитии ряда патологии, в том числе рака, болезни Паркинсона, Альцгеймера и пр. Однако, АФК могут использоваться иммунной системой при деактивации патогенов. Роль окислительного стресса исследуется при разработке противоопухолевых лекарственных средств и прогрессировании заболевания в течение нескольких десятилетий [3]. При окислительном стрессе мишенью активных форм кислорода являются различные клетки и клеточные структуры, в которых происходит окисление высокомолекулярных веществ, таких как белки, липиды, нуклеиновые кислоты. При сильном окислительном стрессе повреждение биомакромолекул приобретает необратимый характер, приводя к гибели клеток. Поддерживает в клетках прооксидантно-антиоксидантный баланс и внутриклеточный редокс-потенциал многоуровневая антиоксидантная система

Цель работы - оценить состояние антиоксидантной и глутатионовой систем крови у здоровых людей.

Задачи: 1) оценить уровень малонового диальдегида в крови здоровых людей, как показателя свободнорадикального окисления липидов; 2) исследовать активность ферментов антиокидантной системы- супероксиддисмутазы, каталазы, востановленного глутатиона, глутатионпероксидазы, глутатион-S-трансферазы.

\section{Материалы и методы исследования}

Обследовано 70 здоровых людей 19-56 лет. На базе Краевого государственного казенного учреждения здравоохранения «Красноярский краевой 
центр крови № 1». Каждым из обследованных было заполнено информированное согласие. Состояние антиоксидантной системы крови оценивали по активности экстрацеллюлярной супероксиддисмутазы, каталазы. Оценку глутатионового звена антиоксидантной системы осуществляли по активности ферментов - востановленного глутатиона, глутатионпероксидазы и глутатион-S-трансферазы. В качестве маркеров окислительного стресса определяли уровень малонового диальдегида. Статистический анализ результатов исследования проводился с помощью пакетов прикладных программ SPSS 8,0 и «Statistica7,0». Проверку гипотезы о статистической достоверности двух выборок проводили непараметрическим методом с помощью критерия Манна-Уитни.

\section{Результаты исследования}

В таблице приведены результаты исследования: активность СОД (3957 \pm 461 ус.ед/мин*гНb), каталазы $(238,8 \pm 5,7$ нмоль*мин/гНb) и фер-

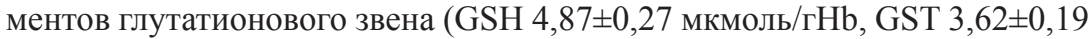
мкмоль/мин/гНb, GPO 49,6 $\pm 1,9$ мкмоль/мин/гНb) и МДА (4,33 $\pm 0,24$ мкмоль/ГНb) в эритроцитах здоровых людей.

\section{Обсуждение}

В состоянии физиологического оптимума антиоксидантный статус организма характеризуется равновесием между двумя противоположными составляющими: уровнем свободно-радикального окисления и активностью антиоксидантной защиты. В обычных условиях это равновесие удерживает перекисное окисление на определенном низком уровне, препятствуя развитию цепных окислительных процессов [5].

\section{Заключение}

Интерпретация результатов исследования показывает, что состояние защитных систем крови (антиоксидантной и глутатионовой) исчерпывающе оценивается определением показателя свободнорадикального окисления липидов (уровень малонового диальдегида), а также определением активности ферментов антиоксидантной системы (SOD, CT, GSH, GPO, GST).

Информация о конфликте интересов. Авторы заявляют об отсутствии конфликтов интересов.

Информация о спонсорстве. Исследование не имело спонсорской поддержки. 


\section{Список литературы}

1. Кривигина Е.В. О генерации активных форм кислорода лейкоцитами и их роли в развитии хронических гастродуоденеальных заболеваний / Е.В. Кривигина Г.Ф. Жигаев // Бюллетень ВСНЦ СО РАМН. Научный центр проблем семьи и репродукции человека: Иркутск. 2011. №1-2. С. 71-74.

2. Masgras I. Reactive oxygen species and mitochondrial sensitivity to oxidative stress determine induction of cancer cell death by p21 / I. Masgras, [et al] // Journal of Biological Chemistry. 2012. T. 287. №. 13. C. 9845-9854.

3. Sosa V. Oxidative stress and cancer: an overview / V. Sosa [et al] //Ageing research reviews. 2013. T. 12. №. 1. C. 376-390.

4. Чанчаева Е.А. Современное представление об антиокидантной системе организма человека / Е.А. Чанчаева, Р.И. Айзман, А.Д. Герасев // Экология человека. 2013. №7. С. 50-58.

\section{References}

1. Krivigina E.V. On the generation of reactive oxygen species by leukocytes and their role in the development of chronic gastroduodenal diseases / E.V. Krivigin, G.F. Zhigaev // Bulletin of the East-Siberian Scientific Center. Research Center for Family Problems and Human Reproduction: Irkutsk. 2011. №1-2, pp. 71-74.

2. Masgras I. Reactive oxygen species and mitochondrial sensitivity to oxidative stress, determine the cell death rate by p21 / I. Masgras, [et al] // Journal of Biological Chemistry. 2012. T. 287. №. 13, pp. 9845-9854.

3. Sosa V. Oxidative stress and cancer: an overview / V. Sosa [et al] // Ageing research reviews. 2013. V. 12. №. 1, pp. 376-390.

4. Chanchayeva E.A. Modern view of the antioxidant system of the human body / E.A. Chanchaeva, R.I. Aizman, A.D. Gerasev // Human Ecology. 2013. №7, pp. 50-58.

\section{ДАННЫЕ ОБ АВТОРАХ}

\section{Круглякова Марина Вячеславовна}

Сибирский Федеральный Университет

пр. Свободный, 79, г. Красноярск, 660041, Российская Федераџия mwk93@mail.ru

Смирнова Ольга Валентиновна, профессор, д-р. мед. наук Сибирский Федеральный Университет; НИИ МПС ФИЦКНЦ СО РАН пр. Свободный, 79, г. Красноярск, 660041, Российская Федераџия ovsmirnova71@mail.ru 
Титова Надежда Митрофановна, доцент, канд. биол. наук Сибирский Федеральный Университет пр. Свободный, 79, г. Красноярск, 660041, Российская Федераџиия tinami6@mail.ru

\section{DATA ABOUT THE AUTHORS}

\section{Kruglyakova Marina Vyacheslovovna}

Siberian Federal University

79, Svobodny pr., Krasnoyarsk, 660041, Russian Federation mwk93@mail.ru

Smirnova Olga Valentinovna Professor, Doctor of Medicine Science Siberian Federal University; Research Institute for Medical Problems in the North

79, Svobodny, Krasnoyarsk, 660041, Russian Federation ovsmirnova71@mail.ru

Titova Nadezhda Mitrofanovna associate professor, Candidate of Biological Sciences

Siberian Federal University

79, Svobodny pr., Krasnoyarsk, 660041, Russian Federation tinami6@mail.ru 